\title{
The 19th Party Congress \\ Personnel Changes and Policy Guidelines
}

Brødsgaard, Kjeld Erik; Høyrup Christensen, Nis

Document Version

Final published version

Published in:

Copenhagen Journal of Asian Studies

DOI:

$10.22439 /$ cjas.v35i2.5447

Publication date:

2017

License

Unspecified

Citation for published version (APA):

Brødsgaard, K. E., \& Høyrup Christensen, N. (2017). The 19th Party Congress: Personnel Changes and Policy Guidelines. Copenhagen Journal of Asian Studies, 35(2), 79-97. https://doi.org/10.22439/cjas.v35i2.5447

Link to publication in CBS Research Portal

\section{General rights}

Copyright and moral rights for the publications made accessible in the public portal are retained by the authors and/or other copyright owners and it is a condition of accessing publications that users recognise and abide by the legal requirements associated with these rights.

Take down policy

If you believe that this document breaches copyright please contact us (research.lib@cbs.dk) providing details, and we will remove access to the work immediately and investigate your claim. 


\title{
The 19th Party Congress: Personnel Changes and Policy Guidelines
}

\author{
KJELD ERIK BRØDSGAARD AND NIS HØYRUP CHRISTENSEN
}

\begin{abstract}
The 19th Congress of the Communist Party of China was held in Beijing October 18-24 2017. Leading up to the congress there was intense speculation concerning the new line-up of the most important leadership bodies of the CPC: the Politburo and the Politburo Standing Committee. Would the Politburo Standing Committee (PSC) continue to consist of seven members, or would it be expanded to nine members, as was the case during Jiang Zemin's era, or would it instead be reduced to five members, as was the case during the late 1980s? Would unwritten rules such as '68 down, 67 up' be observed? Or would veteran leaders such as Wang Qishan (69) continue to serve on the committee? Would Xi Jinping pack the Politburo and the PSC with his own close allies, or would he try to achieve a factional balance observing the interests of former leaders such as Jiang Zemin and $\mathrm{Hu}$ Jintao? There was also much speculation concerning Xi Jinping's status. Would the 'Chairman of Everything' have his name and thought written into the CPC Constitution alongside that of Mao Zedong and Deng Xiaoping and ahead of his two immediate predecessors? $\mathrm{Xi}$ Jinping's report to the Party congress was also awaited with much interest. Such a report is usually a long document setting out the Party's priorities and policy objectives for the next five-year period. Would Xi Jinping's report signal new policy initiatives, and would it outline strategic guidelines reaching beyond 2022? This article examines these questions and assesses the future impact of the Party congress on Chinese politics.
\end{abstract}

\section{Characteristics of the New Politburo Standing Committee}

The day after the conclusion of the Party congress, when the Central Committee met, it was revealed that the new PSC would consist of Secretary General Xi Jinping, Prime Minister Li Keqiang, Head of the Central Committee's Central Office, Li Zhanshu, Vice Prime Minister Wang Yang, Head of the Central Committee's Policy Research Office, Wang Huning, Head of the Central Organization Department, Zhao Leji, and Party Secretary in Shanghai, Han Zheng (see Table1). It was decided 
to maintain a PSC consisting of seven members and it was decided not to change the rule of ' 68 down, 67 up'. Consequently, Xi Jinping's close ally Wang Qishan (69) had to step down, even though there had been much speculation that he might stay on and be promoted to Chairman of the National People's Congress or perhaps even replace Li Keqiang as Prime Minister.

Except for Wang Huning the new leadership is characterized by provincial experience. Li Zhanshu has worked as Party Secretary in Guizhou, Wang Yang has served as Party secretary in both Chongqing and Guangdong, Zhao Leji in Qinghai and Shaanxi, and Han Zheng was appointed Party secretary in Shanghai after having served as mayor for a number of years. Both Xi Jinping and Li Keqiang had long careers in Chinese provinces before moving to the centre in 2007. The new team members are also characterized by having served several periods in the Politburo. Thus, the practice of promoting Politburo members to the PSC according to seniority has been observed once more.

In terms of age, the new members are between 60 and 67. Zhao Leji (60) is the youngest and Li Zhanshu (67) the oldest. Three members Wang Huning, Wang Yang and Li Keqiang - are 62 and can, together with Zhao Leji, be appointed for a new five-year period in the PSC at the 20th Party congress in 2022 without violating the age rule. The average age is 62.9 which is slightly lower than the average age of 63.4 for the Standing Committee elected at the 18th Party congress in 2012 (Brødsgaard 2012a).

\section{New Members of the Politburo Standing Committee}

$\mathrm{X} \mathrm{i}$ Jinping is still ranked number one in his capacity as general secretary of the CPC. At the 19th Central Committee's First Plenary Session immediately following the conclusion of the Party congress, he was re-elected chairman of the Central Military Commission. At the forthcoming meeting of the National People's Congress in March 2018, he will without doubt be elected to another five-year term as president of the PRC. Since the 18th Party congress in 2012, Xi has managed to consolidate his power by moving allies into key provincial and central Party and state positions. Even though the intense anti-corruption campaign has allegedly targeted corrupt elements in the Party, there is no doubt that the campaign has also been used by Xi Jinping to purge political adversaries. ${ }^{1}$ Being 64 years of age, Xi Jinping should step down at the 20th Party congress in 2022, if the '68 down, 67 up' rule 
is followed. Since Wang Qishan has now observed this rule, there is no precedent for Xi Jinping to break with the unwritten age limit for membership of the PSC.

TABLE 1: The Standing Committee of the CCP Politburo (25 October 2017)

\begin{tabular}{|l|l|c|}
\hline Name & Positions & Age \\
\hline Xi Jinping & CCP Secretary General, Chairman of CMC, President & 64 \\
\hline Li Keqiang & Premier of State Council & 62 \\
\hline Li Zhanshu & Director of the General Office of the Central Committee & 67 \\
\hline Wang Yang & Vice Premier & 62 \\
\hline Wang Huning & Director, Policy Research Office of the Central Committee & 62 \\
\hline Zhao Leji & Secretary of the Central Disciplinary Inspection Commission & 60 \\
\hline Han Zheng & Party Secretary, Shanghai & 63 \\
\hline
\end{tabular}

Note: Positions as of 25 October 2017.

Li Keqiang has also kept his ranking as number two in the Party hierarchy. This will secure him another five-year term as prime minister. During the preceding congress period, Li Keqiang has often been characterized as a weak prime minister. Normally the head of the State Council is in charge of economic policy and the formal leader of the Central Leading Small Group of Financial and Economic Work, but $\mathrm{Xi}$ Jinping has taken this position and has placed his close associate in economic affairs Liu He as head of the leading small group's administrative office. Before the congress it was even rumoured that Wang Qishan, who is widely regarded as an able economic planner, might replace Li Keqiang. However, demoting Li Keqiang would upset the factional balance in the upper echelons of the Party and cause political instability, so $\mathrm{Xi}$ Jinping refrained from taking such drastic action.

In the new standing committee, Li Zhanshu is ranked number three and is in line to become Chairman of the National People's Congress. ${ }^{2}$ Li Zhanshu has served as Head of the Central Committee's General Office since 2012. He replaced Ling Jihua who occupied this position during $\mathrm{Hu}$ Jintao's tenure, but was forced to step down due to a scandal involving attempts to cover up his son's fatal car accident in the spring of 2012. ${ }^{3}$ As head of the Central Committee's General Office Li Zhanshu has functioned as Xi Jinping's de facto chief of staff and is thought to be a close ally of the general secretary. He was also member of the Party secretariat of the 18th Central Committee and was appointed Director of the General Office of the National Security Commission, which was established in late 2013. Li previously served as Party secretary in Guizhou province (2010-2012) and has the provincial background and experience that tend to be a sine qua non for making it to the top in 
Chinese politics. Li studied at the Shijiazhuang Institute of Commerce in Shijiazhuang City, Hebei (1971-72). Later he received an undergraduate education in politics from Hebei Normal University, through part-time study and night school education (1980-83). He also studied economics in a correspondence programme at the Central Party School (1992-94). He attended the graduate programme in business economics at the Chinese Academy of Social Sciences (1996-98) and received an EMBA from the Harbin Institute of Technology in Harbin (2005-06), both on a part-time basis.

In terms of factional affiliations $\mathrm{Li}$ is clearly close to $\mathrm{Xi}$ Jinping. The friendship between the two goes back to the early 1980s when Xi served as Party secretary of Zhengding county in Hebei and Li Zhanshu served as Party secretary in Wuji county in the same province. Both counties are administratively part of Shijiazhuang county. Li Zhanshu turned 67 this year and will not be eligible for re-election to the PSC at the next Party Congress.

Wang Yang is ranked fourth among the seven members of the PSC. He has extensive provincial leadership experience, having served as Party Secretary of Chongqing (2005-07) and then Guangdong (20072012). Since 2013, he has worked in Beijing as vice premier in charge of agricultural work. His early career took place in the Chinese Communist Youth League (CCYL) and he was deputy secretary of the CCYL Anhui Provincial Committee (1983-84) before becoming executive vice governor of Anhui province at the age of only 38. While working in the Youth League in Anhui he developed close links with $\mathrm{Hu}$ Jintao who at the time was head of the CCYL. Since then he has been widely believed to be a member of the Youth League faction in the CPC. During his stint in Guangdong province he developed a reputation for being a reformoriented and liberal leader. He was a strong candidate for a membership of the PSC elected in 2012, but was passed over in favour of older and more orthodox members of the Politburo. Wang Yang has studied political economy as well as public administration at the Central Party School in Beijing and later, via part-time study (1993-1995), he received a master's degree in management science from the University of Science and Technology in Hefei, Anhui. He received additional cadre training at the Central Party School. His position as number four in the top hierarchy of the Party would normally make him an obvious candidate to become chairman of the Political Consultative Conference. However, it is rumoured that he might instead take up the position of executive vice premier. This would reduce the political importance of the chairman of 
the Political Consultative Conference. Wang is only 62 and would be eligible for a new five-year term at the next Party Congress.

Wang Huning is ranked fifth in the new leadership line-up. Wang Huning has served in the Central Policy Research Centre of the CPC, since 2002 as Director. ${ }^{4} \mathrm{He}$ is also director of the Central Office of Central Leading Group for Comprehensively Deepening Reform which was formed after the Third Plenary Session in November 2013. Before he was brought to Beijing by Jiang Zemin and Zeng Qinhong in 1995, he made a career in international politics at Fudan University. He served as Professor and Chair of the Department of International Politics (1989-94) and finally as Dean of the Law School (1994-95). He has been a visiting scholar at the University of Michigan and the University of California at Berkeley (1988-89). Unlike other members of the PSC, he has no high-level provincial political and administrative experience and has primarily advanced his career through think-tank work. Also unlike other members of the PSC, Wang Huning has a paper trail indicating his ideological and policy orientation. He is known to promote 'neo-authoritarianism' and centralization of power for the purpose of stronger implementation control. He has successfully served three general secretaries and formulated the theoretical justification for important concepts such as 'three represents' and harmonious society and for Xi Jinping's thought on 'socialism with Chinese characteristics in the new era'. He was originally a member of Jiang Zemin's 'Shanghai Gang', but is now expertly balancing his factional affiliations. Wang is poised to take over Liu Yunshan's positions as executive secretary of the Party Secretariat and president of the Central Party School. It is unusual for an intellectual and academic to rise so high in the Chinese political system. Wang is 62 and would be eligible for another term in the PBSC when the 20th Party Congress convenes.

Zhao Leji is an interesting number six. Unlike Wang Huning, he has extensive provincial experience, working his way up the political-administrative hierarchy in Qinghai to eventually become Governor and Party Secretary of the province. In 2007, he was transferred to Shaanxi province, where he served as Party Secretary during Hu Jintao's second term. In 2012, he was transferred to Beijing to take up the position of Head of the Central Organization Department. This department is in charge of the nomenklatura system and manages appointments for about 4,000 positions at vice-ministerial level and above in the Party, government, state-owned enterprises and other key institutions and organizations (Brødsgaard 2012b). In his position as head of this department, he 
has overseen the promotion of Xi Jinping's protégés. He has now been appointed the new Head of the Central Discipline Inspections Committee and has replaced Wang Qishan as the head of the anti-corruption campaign. Zhao Leji was a 'gongnongbing' (worker-peasant-soldier) student at Peking University in 1977-80 and received an undergraduate degree in philosophy. On a part-time basis, he also attended graduate programmes in banking at the Chinese Academy of Social Sciences (1996-98) and politics at the Central Party School (2002-05). Zhao Leji is clearly close to Xi Jinping and a key member of the so-called 'Shaanxi Gang' which also counts Li Zhanshu among its members. At 60 years of age, he is the youngest of the current PSC members and is eligible for a new five-year term at the next Party congress.

Han Zheng is the most junior person in terms of rank in the new PSC. Throughout his career Han Zheng has worked in Shanghai, mostly in government and Party positions. This governmental career has only been interrupted by two short periods in management positions in rubber plants in Shanghai. He served as mayor in Shanghai for nine years (2003-12) before being appointed as Party Secretary when Xi Jinping left Shanghai to become member of the PSC of the 17th Party Congress. In Shanghai, he has worked with important Party figures such as $\mathrm{Wu}$ Bangguo, Zeng Qinghong, and Yu Zhengsheng, who all later became members of the PBSC. He is widely believed to be a member of the 'Shanghai Gang'. In terms of education he has attended a two-year programme at Fudan University in Shanghai (1983-85) and undertook a part-time undergraduate degree in politics at East China Normal University. He also graduated with a master's in international political economy from this university. Due to his position as number seven in the PSC he probably will be appointed executive vice premier at the next meeting of the National People's Congress in March 2018. However, it is rumoured that he may in fact become head of the Chinese Political Consultative Conference, leaving the vice premiership to Wang Yang. Han Zheng is 63 and will not be eligible for a new term, when the 20th Party Congress meets in 2022.

\section{Consensus and Factional Balance}

The composition of the new PSC indicates an attempt to align the interests of various veteran leaders and their political networks. Wang Yang is associated with the Youth League and is close to Li Keqiang and the former general secretary $\mathrm{Hu}$ Jintao. Han Zheng is part of the 
'Shanghai Gang' headed by Jiang Zemin, and Wang Huning owes his career to his affiliation with Jiang Zemin, who brought him to the Party centre in Beijing. Only Li Zhanshu and Zhao Leji are Xi Jinping's men and are key members of his factional network. It is also interesting to note that there are no clear successors to Xi Jinping and Li Keqiang in the new standing committee. None of them have the right age to serve for two five-year terms when Xi Jinping supposedly steps down in 2022. However, four of them are eligible to be appointed for a new fiveyear period as PSC members. It may also be noted that the educational profile of the PSC has changed. During Jiang Zemin's era, all standing committee members were engineers. During $\mathrm{Hu}$ Jintao's era, engineers were still in the majority in the top leadership. Now economists are the most numerous among standing committee members (Li Keqiang, Li Zhanshu, Han Zheng), but there is also one political scientist (Wang Huning), one member with a master's in management science (Wang Yang) and even one member with a degree in philosophy (Zhao Leji). $\mathrm{Xi}$ Jinping has a master's degree in chemical engineering, but his $\mathrm{PhD}$ is in Marxist law. Several have received their higher education through part-time study, supplemented by graduate programmes and cadre training at the Central Party School.

\section{The New Politburo}

At the first plenary session of the 19th Central Committee held the day after the conclusion of the Party congress, 15 new members were elected to replace those members of the Politburo that had to retire due to age requirements. The average age of the new members is 62.4 compared to 61 in 2012. New members include several regional leaders, such as the Party secretaries of Bejing (Cai Qi), Tianjin (Li Hongzhong), Jiangsu (Li Qiang), Liaoning (Li Xi), Xinjiang (Chen Quanguo) and Chongqing (Chen Min'er). Some of these were only recently appointed provincial leaders. Cai Qi, for example, was not even member of the Central Committee when in May 2017 he was appointed Party secretary in Beijing, and Chen Min'er only moved to Chongqing in July 2017, following the purge of Sun Zhengcai.

Other new members of the Politburo include Ding Xuexiang, the deputy director of the Central Committee's General Office; Huan Kunming, the executive minister of the Central Propaganda Department; Wang Chen, vice chairman of the NPC; Liu He, vice minister of the National Development and Reform Commission (NDRC) and director of the office 
of the Central Leading Group for Finance and Economics; Yang Jiechi, state councillor and former minister of foreign affairs; Yang Xiaodu, minister of the Ministry of Supervision; Chen Xi, executive minister of the Central Organization Department; Guo Shengkun, minister of the Ministry of Public Security; and PLA general Zhang Youxia, director of the PLA General Armaments Department. Three members were not reelected even though they were eligible in terms of age. They include vice president Li Yuanchao; minister of propaganda Li Qibao, and former Party secretary of Xinjiang province, Zhang Chunxian.

TABLE 2. Composition of the Politburo of the 19th Central Committee of the CCP (25 October 2017)

\begin{tabular}{|l|c|l|}
\hline Name & Age & Position \\
\hline Xi Jinping & 64 & Secretary General, President, CMC Chair \\
\hline Li Keqiang & 62 & Premier of State Council \\
\hline Li Zhanshu & 67 & Director, General Office of the Central Committee \\
\hline Wang Yang & 62 & Vice Premier \\
\hline Wang Huning & 65 & Director, Policy Research Office of the Central Committee \\
\hline Zhao Leji & 60 & Secretary of CCDI \\
\hline Han Zheng & 66 & Party Secretary, Shanghai \\
\hline Ding Xuexiang & 55 & Deputy Director, General Office of the Central Committee \\
\hline Li Qiang & 58 & Party secretary, Jiangsu \\
\hline Li Hongzhong & 61 & Party secretary, Tianjin \\
\hline Huan Kunming & 61 & Executive vice minister, Central Propaganda Department \\
\hline Xu Qiliang & 67 & Vice Chairman of the CMC \\
\hline Sun Chunlan (f) & 67 & Minister, United Front Department \\
\hline Wang Chen & 67 & Vice chairman, National People's Congress \\
\hline Liu He & 66 & Vice minister, NDRC \\
\hline Chen Xi & 62 & Executive vice minister, CCP Central Organizational \\
\hline Hu Chunhua & 54 & Party Secretary, Guangdong \\
\hline Chen Quanguo & 61 & Party Secretary, Xinjiang \\
\hline Zhang Youxia & 67 & Vice Chairman of the CMC \\
\hline Guo Shengkun & 63 & Minister of Public Security \\
\hline Li Xi & 61 & Party Secretary, Liaoning \\
\hline Chen Min'er & 57 & Party Secretary, Chongqing \\
\hline Yang Jiechi & 67 & State Councillor \\
\hline Cai Qi & 61 & Party Secretary, Beijing \\
\hline Yang Xiaodu & 58 & Minister of Supervision \\
\hline
\end{tabular}

Source: Author's database.

Note: Positions at the time of appointment. Politburo Standing Committee members in grey shadow. 
There has already been some reshuffling of leadership positions. Ding Xuexiang has been appointed new head of the Central Committee's General Office; Huan Kunming is the new minister of the Central Propaganda Department and Chen Xi is the new minister of the Central Organization Department. Li Qiang has left Jiangsu to become Party Secretary in Shanghai following Han Zheng, and Li Xi has been moved to Guangdong to replace Hu Chunhua, who is currently waiting for a new appointment, possibly as vice premier.

There are some interesting profiles among the new Politburo members. Liu He, for example, is a key figure in economic policy planning. He works closely with Xi Jinping as director of the General Office for the Central Leading Group for Financial and Economic Affairs. He graduated in economics from Renmin University in Beijing and also holds a Masters degree in public administration from the Kennedy School at Harvard University. Yang Jiechi is the first former foreign minister and international relations expert to be elected as a member of the Politburo since Qian Qichen, who was a member of the 14th and 15th Politburo of the CPC. Chen $\mathrm{Xi}$ is a close personal friend of $\mathrm{Xi}$ Jinping and his former roommate at Tsinghua University. He has now been promoted to head the Central Organization Department and has also been appointed to the CPC secretariat. The placement of Chen $\mathrm{Xi}$ in these key positions, combined with Zhao Leji's appointment to head the Central Disciplinary Inspection Commission, will ensure Xi Jinping's control over personnel issues in the CPC.

Guo Shengkun is a former head of China Aluminium Corporation and is an example of how leaders of large SOEs are integrated in the Chinese power system by way of the cadre rotation system (Brødsgaard 2012c). In 2004, Guo was transferred to Guangxi to serve as deputy Party secretary and later Party secretary. In 2012, he became minister of Public Security. Other former business executives who are making a career in Party and government include Zhang Qingwei, former president of China Aerospace and current Party Secretary of Heilongjiang; Ma Xingrui, also former president of China Aerospace and current governor of Guangdong; and Zhang Guoqing, former CEO of China Northern Industries and current mayor of Chongqing. Some of them may advance to become members of the Politburo in 2022.

Chen Min'er was transferred from Guizhou in July 2017 to replace Sun Zhengcai as Party secretary of Chongqing. Since this appointment would almost certainly secure him a seat on the Politburo, the transfer caused widespread speculation that Chen Min'er was Xi Jinping's 
preferred candidate to succeed him as Party leader. Chen Min'er has spent most of his career in his native Zhejiang and climbed the career ladder to become vice governor of Zhejiang before he was transferred to Guizhou in 2012 to become deputy Party secretary and later Party secretary. During his time in Zhejiang he became closely associated with Xi Jinping. Aged 57 he is young enough to take over when Xi steps down. However, he did not make it to the standing committee, which would jeopardize the rule that new standing committee members are selected from within the Politburo.

$\mathrm{Hu}$ Chunhua was another candidate for inclusion in the standing committee. $\mathrm{Hu}$ Chunhua, also called 'Little $\mathrm{Hu}^{\prime}$, was widely assumed to be $\mathrm{Hu}$ Jintao's top candidate to become general secretary. He is a member of the Youth League faction and in fact served as first secretary of the CCYL Central Committee before becoming governor of Hebei province in 2008, Party secretary of Inner Mongolia Autonomous Region in 2009, and Party secretary of Guangdong province in 2012. Aged 54 he was a perfect choice if the Party leadership wanted to observe the unwritten rule that the chosen successor must be groomed during a five-year congress period before taking over as general secretary for a ten-year period. When Sun Zhengcai, also aged 54, was purged, it was an indication that this rule might no longer apply. Following the Party congress Hu Chunhua was replaced as Guangdong Party secretary by Li Xi. Since no corruption charges have been levelled against him, he will presumably be promoted to vice premier. Given the importance of Guangdong, transferring him to head a new province would imply a demotion.

There is a third member of the new Politburo who is the right age to succeed Xi Jinping. This is Ding Xuexiang, Li Zhanshu's executive deputy director in the General Office of the Central Committee and director of the Office of the General Secretary. He was Xi Jinping's chief of staff in Shanghai and he followed Xi to Beijing in 2007. Ding Xuxiang made his career in Shanghai and has worked for Han Zheng and the outgoing standing committee member from Shanghai, Yu Zhengsheng. He has also been secretary of the CCYL Committee in Shanghai. These experiences and affiliations would make Ding Xuexiang an ideal consensus candidate for current and former top Party leaders, including $\mathrm{Hu}$ Jintao and Jiang Zeming. Ding Xuexiang is 55 years of age and the second youngest after $\mathrm{Hu}$ Chunhua in the new Politburo. 


\section{Xi Jinping's People}

Whereas the composition of the PSC reflects consensus among competing factions, the new Politburo is dominated by Xi Jinping's allies. Since members of the PSC are usually promoted from the Politburo, this will provide Xi the opportunity to form a PSC primarily consisting of his close supporters and allies in 2022.

All four major, provincial-level cities - Beijing, Tianjin, Shanghai, Chongqing - continue to be represented in the Politburo, indicating the political significance of these megacities. Chen Min'er in Chongqing, Cai Qi in Beijing and Li Hongzhong in Tianjin all belong to Xi's network and the replacement of Han Zheng in Shanghai will undoubtedly also be one of his close associates. ${ }^{5}$ The economic powerhouse of Guangdong and the strategically important Xinjiang also regained their seats in the Politburo. In the case of Guangdong, Hu Chunhua may soon be replaced by someone closer to $\mathrm{Xi}$.

Important central Party departments such as the Central Organization Department, the Central Propaganda Department, and the United Front Department are still represented on the Politburo, whereas only two ministries have sufficient political clout to be represented by their ministers, Guo Shengkun of the Ministry of Public Security and Wang Xiaodu of the Ministry of Supervision. ${ }^{6}$ In the case of the latter, his role as deputy director of the CPC's Central Disciplinary Inspection Committee has probably been the main argument for electing him to the new Politburo.

\section{Xi Jinping enters the Party Constitution}

Since his election to general secretary of the CPC in 2012, Xi Jinping has acquired so much power that many observers have dubbed him the most powerful Chinese leader since Deng, and possibly since Mao. With this in mind, it was anticipated by most observers that $\mathrm{Xi}$ Jinping would get his name into the Party constitution. The way it was done, however, was surprising. The straightforward way would have been with a reference to 'The Four Comprehensives' that has been step-wise developed under $\mathrm{X} i$ and promoted accordingly. Instead $\mathrm{Xi}^{\prime}$ 's name entered the constitution with a link to Deng Xiaoping's old and inherently pragmatic ideological guideline: 'Socialism with Chinese Characteristics'. This means that the full line of CPC guiding ideology is now: 'Marxism-Leninism, Mao Zedong Thought, Deng Xiaoping Theory, the 
Theory of Three Represents, the Scientific Outlook on Development, and Xi Jinping Thought on Socialism with Chinese Characteristics for a New Era' (Xinhua 2017a). ${ }^{7}$

What is also striking is the fact that $\mathrm{Xi}^{\prime}$ 's ideological contribution is listed as a 'Thought'. Ideologically speaking, this brings $\mathrm{Xi}$ 's contribution on par with 'Mao Zedong Thought' even though 'socialism with Chinese characteristics' - the main content of Xi Jinping Thought - is actually Deng's invention. Yet, the fact that the label 'Thought' is applied sends an unequivocal signal of Xi's control of the Party and indicates his pivotal role for politics in China even beyond the next five years. Beyond the political discourse this similarity with Mao's standing is also an easily recognizable signal that will work to cement $\mathrm{Xi}^{\prime}$ s outstanding position in the eyes of ordinary Chinese.

How then are we to understand Xi Jinping Thought? In terms of content, it is explained through eight points that make clear the overall means and ends, and as many as 14 fundamental principles that include upholding party leadership, deepening reform, law based governance, upholding core socialist values, improving people's livelihood, ecological civilization, national security, contributing to global development and maintaining the international order. These principles include 'The Four Comprehensives' but are broader and more encompassing. In fact, Xi Jinping Thought seems to be so all-encompassing that it becomes difficult to see what new guidance it actually provides.

A comparable perspective to Jiang Zemin and $\mathrm{Hu}$ Jintao's previous contributions highlights some of the main differences in terms of political and organizational impact (Holbig 2009). Jiang Zemin's 'Theory of Three Represents' enabled an important re-organization of the CPC by including private entrepreneurs. This shift was crucial for the CPC's ability to include an increasingly important segment of society - private businessmen - in the Party and thereby avoid the establishment of a powerful interest group outside the party. Hu Jintao's 'Scientific Outlook on Development' provided a much-needed change in the economic trajectory towards a more sustainable type of development (Christensen 2013). This marked the start of China's green agenda with, for instance, a massive surge in investments in renewable energy. Seen in relation to these two previous contributions to the Party's ideological base, Xi Jinping Thought is not in any way as concrete or policy-oriented. It offers no new means and offers only light revisions of the old ones.

Instead ' $\mathrm{Xi}$ Jinping Thought' designates a coming era, which is a new ideological twist in the sense that both Mao Zedong Thought and Deng 
Xiaoping Theory were signifying a totality of past achievements, but not a period as such. The personal name tag is therefore for the first time linked to a specific - and even future - period and not granted in retrospect with reference to past accomplishments. With respect to the use of periods in the Party ideology we can see how it has been an integral part of the CPC's goal setting since the 12th Party congress in 1982. Here, Deng announced that China should quadruple the annual industrial and agricultural output by the end of the millennium (Thompson 2009). ${ }^{8}$ However, China reached this milestone three to four years ahead of schedule and was thus left in a 'periodic limbo' until the 16th Party congress in 2002 where Deng Xiaoping's old vision of reaching a moderately prosperous (xiaokang) society was re-announced with a 2020 target date. It is this periodization to which Xi Jinping Thought is now linked.

The new era of 'Socialism with Chinese Characteristics' that we are now said to enter will also confirm a new role for China on the international stage. In fact, the new era is directly linked to a growing pride in China as a model for other nations:

[s]ocialism with Chinese Characteristics has kept developing, blazing a new trail for other developing countries to achieve modernization. It offers a new option for other countries and nations who want to speed up their development while preserving their independence; and it offers Chinese wisdom and a Chinese approach to solving the problems of mankind (Xinhua 2017b).

This type of externally-oriented confidence in China as a model to emulate for other countries is new in the Party ideology. When seen in the context of increasing assertiveness in the foreign policy posture and role as initiator (most notably of the Belt and Road Initiative and Asia Infrastructure Investment Bank) that Xi has already promoted, it adds up to a very mature and confident China ushering in a new era on the world stage. And given the lack of new policy guidelines and measures in Xi Jinping Thought, this confidence in the Chinese model could very well be one of its most important features.

\section{Xi Jinping's Report to the 19th National Congress}

Xi Jinping's report is a lengthy document (66 pages) with several important ideological and developmental guidelines. These include the outline of Xi Jinping Thought (as explained above), but also a change in the 'primary contradiction', new goals for China's future development, 
and several statements that enable us to assess the economic implications of this 19th National Congress.

The report presents a change in the 'primary contradiction of the Chinese society,' which has the potential to be a very significant change in the ideological base of the Party. The primary contradiction prior to the Party congress was between the 'needs of the people' and China's 'backward social production'. This primary contradiction stood for 36 years and at the time of its introduction it reflected a fundamental shift in the focus of the Party where Deng managed to release China from the shackles of class struggle. After the 19th Party congress, however, the primary contradiction is now described as being between unbalanced and inadequate development' and the 'people's ever-growing needs for a better life'. The 'needs of the people' are now described with more sophistication as 'needs for a better life,' and more significantly the 'backward social production' is replaced with the tension arising from 'unbalanced and inadequate development'. To appreciate the significance of the change we can view it as a shift from a focus on 'growth at all cost' to a much more nuanced conception of balanced development. This type of development takes into consideration the often-conflicting aims of environmental protection, health, social fairness, growth, increasing energy consumption, etc. In other words, this is a China that is about to struggle with the same set of trade-offs as developed countries.

However, the change in primary contradiction not only signals a new political orientation, it will also function as a new source of legitimacy for the CPC's policy-making. This double role of the primary contradiction reflects the often tautological way in which the CPC explains China's development trajectory by pointing to a continuous need to do what is required to keep up with the times (a destined history), and thereby hide the fact that the CPC has actually charted that course itself. This mechanism is now updated and ready for the next chapter in China's modernization. To be a little more concrete, we could for instance speculate that this shift in primary contradiction will have an impact on the future evaluation criteria for high-level Party members under the nomenklatura. In this way, the hitherto strong focus on economic progress would be supplemented with other more broadly defined criteria.

\section{Launch of New Targets}

One of the most distinct features of the CPC's ideological work is the use of long-term goal-setting. The 19th Party Congress will, in this respect, 
stand out as significant because of the launch of a new 2050 vision and - perhaps more importantly - the milestones in between. First of all, the report points out that the few years until 2020 will be dedicated to 'finishing the building of a moderately prosperous society in all respects'. This milestone will then be reached right at the point where the CPC can also celebrate its centenary. Secondly, the goal of building a fully modern socialist country by 2050 was proclaimed. To get there, two phases running from 2020 to 2035 and 2035 to 2050 respectively were listed with specific socio-economic milestones. It is important to take stock of the first, upcoming phase: ${ }^{9}$

- China's economic and technological strength has increased significantly. China has become a global leader in innovation.

- The rights of the people to participate and to develop as equals are adequately protected. The rule of law for the country, the government and society is basically in place. Institutions in all fields are further improved; the modernization of China's system and capacity for governance is basically achieved.

- Social etiquette and civility are significantly enhanced. China's cultural soft power has grown much stronger; Chinese culture has greater appeal.

- People are leading more comfortable lives, and the size of the middle-income group has grown considerably. Disparities in urbanrural development, in development between regions, and in living standards are significantly reduced; equitable access to basic public services is basically ensured; and solid progress has been made toward prosperity for everyone.

- A modern social governance system has basically taken shape, and society is vital, harmonious and orderly.

- There is a fundamental improvement in the environment; the goal of building a Beautiful China is basically attained.

The breadth and depth of this 2035 blueprint is significant and the level of ambition for what has to be achieved is notable. The relatively short time horizon also prompts immediate action.

In the second phase, from 2035 to 2050, China will build on the basic modernization achieved in the previous phase and will aim to meet the following targets:

- New heights are reached in every dimension of material, political, cultural and ethical, social and ecological advancement.

- Modernization of China's system and capacity for governance is achieved. 
- China has become a global leader in terms of composite national strength and international influence.

- Common prosperity for everyone is basically achieved.

- The Chinese people enjoy happier, safer and healthier lives.

With these targets met, China will have become a fully modern (socialist) country right at the point where the People's Republic of China can celebrate its centenary. The importance of this kind of numerology might be lost on a Western audience, but should not be underestimated as a driver for the CPC.

\section{Economic Implications}

The overall impression of a historically strong leader obviously enables a better chance of implementing the proposed and ongoing reforms as laid out in the 60 Decisions Economic Reform Program launched at the Third Plenum in 2013. This is important because reforms within areas like labour reform, competition policy, cross-border investment policy and fiscal policy reform are currently lagging behind (Asia Society 2017). ${ }^{10}$ The ongoing supply-side structural reforms to cut over-capacity, deleverage, and invest in new technology industries will continue and is now written into the Party Constitution.

Interestingly, the report not only reiterates the commitment to 'deepen reform, it also calls for a commitment to break through the blockades of vested interests. ${ }^{11}$ Such a blunt statement is indicative of the problems China's long-heralded reform pace has faced in later years.

The report also provides important insights into the envisioned role of the state sector. On the one hand, we are promised further reform of SOE's along well-known lines like developing mixed-ownership structures as well as structural adjustments and reorganization. On the other, we find calls for further support for state capital in becoming stronger, doing better and growing bigger. The final aim is to build world-class competitive Chinese companies. What is evident from these statements is the seemingly paradoxical nature of the orientation of reform. This suggests that the continuities will far outweigh the revisions and that the role of SOEs as vehicles for Beijing's global ambitions still prevails. This is a role that has gathered momentum with the launch of the Belt and Road Initiative.

Relatedly, foreign investors are promised a significant ease of market access and, specifically, a change in regulations featuring a negative list for market access. For instance, service sectors are mentioned as targets 
for further opening. It is furthermore stated that foreign investors will be protected and all businesses treated equally. While there remains ample room to push ahead in these areas, the concomitant strengthening of state capital will prove a significant barrier to how far the equal treatment can actually go. We can therefore expect incremental steps rather than a complete turnaround on past practices.

It is also interesting to note how the report calls for 'full play' to the strategic guidance of national development plans on the one hand, and repeats the plea from the Third Plenum to let the market play a decisive role in the allocation of resources on the other. When seen in relation to the lack of explicit break with the industrial policy-making featuring strategic sectors, state subsidies, and state policy banks, as well as no direct downgrading of the hitherto pivotal role of the National Development and Reform Commission, it is obvious that the retreat of the state will at best be incremental.

While the above mostly points to incremental steps, it should be stressed that on the macroeconomic level the change in primary contradiction actually holds significant potential for a reorientation of the economic policies and, as mentioned, a less growth oriented perspective. In a broad sense, this means that the ideological base now makes up a much stronger platform for carrying out the projected rebalancing of the economy.

\section{Conclusion}

The 19th Party congress took place in an orderly fashion without the open and dramatic power struggle that characterized the 18th Party congress. A new PSC was elected, and consisted of experienced senior Party leaders. Unwritten rules concerning retirement age were observed and Wang Qishan stepped down accordingly. The composition of the new PSC reflects consensus politics and an attempt to balance factional interests, whereas the composition of the new Politburo to a much higher degree reflects $\mathrm{X}$ Jinping's political and personal preferences. The succession issue was left unresolved and in the coming congress period this will stimulate speculation as to whether Xi might stay on, either as general secretary or in some other dominant role after 2022.

By writing Xi Jinping and his thought on 'socialism with Chinese characteristics for a new era' into the Party constitution, the Party has elevated Xi to a position on par with Deng and perhaps Mao. This signals continuity and stability, and ensures an impression of revolutionary 
legitimacy for Xi Jinping's rule. The new era will last for more than 30 years until 2050, when the People's Republic of China has celebrated its centennial. The organizational and ideological force to successfully achieve this goal remains a strong and centralized CPC in the eyes of Xi Jinping and his associates.

The 19th Party Congress in no way presaged a return to basic economic and political reform. On the contrary, the clear message is that 'the Party must be everywhere'. Xi Jinping may be likened to Deng Xiaoping but in terms of their views of the role of the Party, there are clear differences. Deng Xiaoping sought to restrict the role of the CPC rather than involve the Party in matters that might be better handled by government, business or social organizations. Xi Jinping is engaged in micromanagement, Deng Xiaoping was not.

Kjeld Erik Brødsgaard is Professor of China Studies, Department of International Economics and Management and Director of China Policy Program, Copenhagen Business School. His current research covers state-Party-business relations; the nomenklatura system and cadre management; Party reform and elite politics; the structure and impact of Chinese business groups; the rise of Chinese supermanagers; and Chinese economic thinking and development. Email:keb.int@cbs.dk

Nis Høyrup Christensen is Assistant Professor, Asia Research Centre, Department of International Economics and Management, Copenhagen Business School. His research interests evolve around China's state capitalist model, the dynamics of business/government relations, and the mechanisms driving China's efforts to achieve a more sustainable economic and environmental trajectory.Email:nhc.int@cbs.dk

\section{NOTES}

1 For a more detailed discussion of the career background of Xi Jinping and Li Keqiang, see Brødsgaard (2012a): 61-73.

2 The following biographical information is mainly based on Zhongguo renwu nianjian 2016; the online individual China vitae; a series of biographies of new Politburo Standing Committee members posted online by John L. Thornton Centre at Bookings Institution, Washington, as well as the authors' database.

3 He was later purged and in July 2016 sentenced to life in prison. See Heilmann (2017:185).

4 See also Patapan and Wang (2017).

5 Following the Party Congress Li Qiang, Party secretary of Jiangsu, was transferred to Shanghai, to replace Han Zheng and Li Xi, Party secretary of Liaoning, was 
transferred to Guangdong to replace $\mathrm{Hu}$ Chunhua.

6 After the Party congress Guo Shengkun was appointed Party secretary of the Political and Legal Affairs Commission. It is reported that he will be replaced as minister of Public Security by Zhao Kezhi, former Party secretary of Hebei, who is not a member of the Politburo.

7 Xinhua 2017a. 'Full text of resolution on amendment to CPC Constitution,' Xinhua News Agency. http://news.xinhuanet.com/english/2017-10/24/c_136702726.htm. Accessed November 2017.

8 Thompson, Drew 2009. 'Beijing's GDP Numerology,' Foreign Policy. Available at http://foreignpolicy.com/2009/03/10/beijings-gdp-numerology/.

9 Xinhua (2017b). 'Full text of Xi Jinping's report at 19th CPC National Congress,' Xinhua News Agency. Available at http:/ / www.xinhuanet.com/english/download/ Xi_Jinping's_report_at_19th_CPC_National_Congress.pdf.

10 Asia Society (2017). The China Dashboard. Available at http://chinadashboard. asiasociety.org/china-dashboard/.

11 Xinhua (2017b). 'Full text of Xi Jinping's report at 19th CPC National Congress,' Xinhua News Agency. Available at http://www.xinhuanet.com/english/download/ Xi_Jinping's_report_at_19th_CPC_National_Congress.pdf.

\section{REFERENCES}

Brødsgaard, Kjeld Erik 2012a. 'A Note on the 18th party Congress: Personnel Changes and Factional Alliances,' The Copenhagen Journal of Asian Studies 30( 2): 61-73.

Brødsgaard, Kjeld Erik 2012b. 'Politics and Business Group Formation in China: The Party in Control?' The China Quarterly 211: 624-648.

Brødsgaard, Kjeld Erik 2012c. 'Cadre and Personnel Management in the CPC,' China: An International Journal 10(2): 69-84.

Christensen, Nis H. 2013. Shaping Markets: a Neoinstitutional Analysis of the Emerging Organizational Field of Renewable Energy in China. Frederiksberg: Copenhagen Business School (PhD thesis).

Heilmann, Sebastian (ed) 2017. China's Political System. London and New York: Rowman \& Littlefield.

Holbig, Heike 2009. 'Remaking the CCP's Ideology: Determinants, Progress, and Limits under Hu Jintao,' Journal of Current Chinese Affairs 38(3): 35-61.

Patapan, Haig and Wang Yi 2017. 'The Hidden Ruler: Wang Huning and the Making of Contemporary China,' Journal of Contemporary China (August): 1-14.

Zhongguo renwu nianjian 2016. Beijing: Zhongguo renwu nianjian she. 